\title{
Evaluation of maximun damping factor -Ing. EVALUATION OF MAXIMUM DAMPING FACTOR OF A STEEL FACESHEET -PVC FOAM CORE SANDWICH BEAM BY USING ANSYS
}

\author{
Lino Angelo Giallamine ${ }^{1}$, Ing Lino $^{1}$, and Angelo Giallamine ${ }^{1}$ \\ ${ }^{1}$ Italian Navy Lieutenant
}

December 8, 2020

\begin{abstract}
This paper aims to identify, through harmonic analysis, the damping factor of a sandwich beam for which is maximal the reduction of internal stress. The general idea is to promote the use of harmonic analyses at design time to fairly accurately estimate the dissipative capacity of the system. After introducing the theoretical notions of the laws that govern beam dynamics, we will discuss the results of a parametric analysis conducted through the FEA software ANSYS.
\end{abstract}

\section{Hosted file}

EVALUATION OF MAXIMUM DAMPING FACTOR.pdf available at https://authorea.com/users/381839/ articles/497736-evaluation-of-maximun-damping-factor-ing-evaluation-of-maximum-dampingfactor-of-a-steel-facesheet-pvc-foam-core-sandwich-beam-by-using-ansys 